\title{
Oyster Shell Waste (Crassostrea Gigas) as A Cheap Adsorbent for Adsorption Of Methylene Blue Dyes: Equilibrium and Kinetics Studies
}

\author{
Muhammad, Nia Afriani, Meriatna*, Rizka Mulyawan \\ Department of Chemical Engineering, Faculty of Engineering, Universitas Malikussaleh, Aceh, Indonesia \\ *Corresponding author E-mail: meriatna@ unimal.ac.id
}

\begin{abstract}
Manuscript received 15 August 2021; revised 1 Sept 2021; accepted 15 Sept 2021. Date of publication 4 Nov 2021
Abstract

In this study, Oyster (Crassostrea gigas) shell powder which contains calcium carbonate $\left(\mathrm{CaCO}_{3}\right)$ was converted into calcium oxide $(\mathrm{CaO})$. The Oyster shell powder that had been activated was utilized for the adsorption of the methylene blue (MB) dyeing material, which is one of waste water concerns. Oyster shells were crushed and sieved into 100 mesh sized powder and then calcinated at a temperature of $600^{\circ} \mathrm{C}$ and $800^{\circ} \mathrm{C}$ both for 4 hours period. To determine the adsorption equilibrium, methylene blue (MB) solution was used with varying concentration from 10 to $50 \mathrm{mg} / \mathrm{L}$ in which the adsorbent weighing $3 \mathrm{~g}$ was put into a conical flash and shaken until the adsorption equilibrium was reached. As for the adsorption kinetics, $250 \mathrm{~mL} \mathrm{MB}$ solution was used with initial concentrations of $10,20 \mathrm{and} 30 \mathrm{mg} / \mathrm{L}$, with an adsorbent weight of $3 \mathrm{~g}$ and a solution at $\mathrm{pH} 11$ for each concentration. The evaluation of the experimental data from the adsorption process is well explained by the Freundlich equation, with the correlation coefficient value $\left(R^{2}\right)$ found to be 0.9999 , where the value of the adsorption intensity $(n)$ is close to unity; this shows that the adsorption is multilayer or in other words the adsorption energy is heterogeneous. The kinetics study also shows that pseudo second-order model is the most applicable to the adsorption process. From the pseudo-secondorder model, with the correlation coefficient between $0.9984-0.9999$ can explain that the methylene blue (MB) adsorption process is chemically based sorption or in other words termed as chemisorption.
\end{abstract}

Keywords: Adsorption, Oyster Shell, Equilibrium, Kinetics, Methylene Blue.

\section{Introduction}

Indonesia has huge potency in fisheries sector. The sea biodiversity is also varied, among them is Oyster (Crassostrea gigas) and bivalve species as one of the commodities that potentially increases Indonesia foreign exchange. There has been oyster exporting countries from Indonesia such as Japan, China, Singapore and other countries. Oyster is also highly demanded both in local and international markets [1]. Oyster has unique taste that later developed as processes food. Processed oyster only utilizes its meat, while its shell goes as waste. Oyster processing in Indonesia is identical to Tiban island due to local people utilize it to sell both uncooked and processed. From the oyster processing, it also generates shell waste that can pollute the environment [2].

Hence it is necessary to handle the oyster shell waste. Like the waste from squid (Sepia officinalis), it has potential to be utilized to be added value product[3]. Considering the content of Oyster shell, it is potential source of calcium as it consists more than $60 \% \mathrm{CaO}$ compound and chitin, thus it is a good adsorbent source [4] [5]. Chitosan as adsorbent has been used for waste water treatment for heavy metal adsorbent, dyeing waste water and aquaculture waste water [6] [9]. Dyes is a great concern as waste water effect, since it may suppress bacterial growth in water, causing insufficient bacterial level that acts in biological degradation [10] [11].

Groundwater is the main source of drinking water. At big cities, groundwater is often polluted with waste that mostly contaminated with dying material containing poisonous organic and inorganic acid, base and also heavy metals. Consequently, it is big challenge to remove dying material from waste that flows to rivers due to complexity of waste water treatment with chemical oxidation and biological methods. Adsorption technique is proved to be an efficient and economical process to adsorb dying material [12] [13] [14]. The process efficiency is based on the appropriate preference of adsorbent. An ideal adsorbent should be widely available, cheap and economically not valuable. In this research oyster shell powder was used as adsorbent and methylene blue as the adsorbate. Methylene blue is thiazine dying material with chemical formula $\mathrm{C}_{16} \mathrm{H}_{18} \mathrm{CIN}_{3} \mathrm{SCI}$ that has properties of basic or cationic and soluble in water [15]. Methylene Blue is one of simulated dye wastewater beside Methyl Orange[16].

The aim of this research was to evaluate the adsorption mechanism, using Langmuir and Freundlich isotherm models on Methylene Blue (MB) adsorption using oyster shell as the adsorbent. Besides, adsorption kinetical reaction rate constant was also calculated using second order model, pseudo second order and Ritchie model [17]. 


\section{Literature Review}

\subsection{Oyster}

Oyster is a member of scallop group that has calcium and plain shaped shell. Oyster is bivalvia type that is in the family of Ostreidae. In general, Oyster has several names such as Giant Oyster, Giant, Pacific Oyster, Gigas, Portuguese Oyster, Immigrant Oyster, Japanese Oyste [18]. Chemical composition of oyster shel 1 is $94.78 \%$ ash, $0.11 \% \pm 0.03$ water, $1.69 \% \pm 0.40 \mathrm{~N}-$ Total and fat $1.43 \% \pm 0.26$ [19].

\subsection{Adsorption}

Adsorption is both physical and chemical process that binds matter on to another matter's surface. The process takes place either on solids or liquids and multilayered based process. Adsorption takes place between solids and liquids, and solids and gas [20]. Adsorption is determined from the concentration change on surface due to accumulation of interfacial unbalanced tension resulting from physisorption processes such as Van der Walls and hydrogen bond, or chemisorption. The energy needed by chemisorption is relatively higher compared to physisorption. There are factors affecting adsorption such as concentration, surface area, temperature, particle size, $\mathrm{pH}$ solution and contact time [20].

\subsection{Adsorption Isotherm}

Adsorption isotherm shows equilibrium relation between bulk adsorbate concentration and inside particle adsorbent concentration at constant temperature. Equilibrium takes place when adsorbent to adsorbate binding rate equals to its unbinding rate. Adsorption isotherm can be used to study chemical adsorption mechanism. There are models describing adsorption isotherm such as Langmuir and Freundlich isotherm models [20].

The followings are assumptions for Langmuir approach:

1. The adsorbed gas behaves ideally.

2. The adsorbed gas covers monolayer area.

3. Homogeneous adsorbed surface; binding affinity for every gas molecule is the same.

4. Absence of lateral interaction between adsorbate molecules.

5. Static position of adsorbed molecules.

Freundlich isotherm equation is based on monolayer formation of adsorbate molecules on adsorbent. Freundlich isotherm describes relations between adsorbed molecules in adsorbent units and concentrations at equilibrium.

\subsection{Adsorption Kinetics}

Adsorption kinetics shows presence of adsorption process by adsorbent as function of time. It refers to rate of adsorbate adsorption on adsorbent. Its application in waste treatment is essential to comprehend the chemical reactions and adsorption mechanism. Empirical approaches are first, second, pseudo-first and pseudo-second orders. First order reaction depends on only one of the reactants [21]. Second order reaction has rate which is proportional to product of both of the reactants or in quadratic form [22]. Pseudo first order adsorption kinetics equation is based on the adsorbate capacity on adsorbent with the assumption of adsorbate concentration is more than active sites of adsorbent surface [23]. Pseudo second order model is one of the most recent proposed models and generally describes adsorption process dynamics.

\subsection{Methylene Blue}

Dyeing material is organic compound that contains chromophore groups as auxochromes to bind the colors. It is classified into anionic, cationic and nonionic. Among them anionic is usually used as Batik dyeing material [20]. Methylene blue is one of thiazine dyeing material that is easy to find and economics. This basic material is usually used as paper, hair, clothes, and wool dyeing material. This dyeing material negatively affects health if swallowed and irritating on skin.

Methylene blue has been utilized to study adsorption process of organic impurities in liquids and its adsorption kinetics also well understood on chitin and chitosan that follows second order reaction [24].

\section{Methods}

\subsection{Materials}

The utilized oyster shell waste was collected from Ujong Blang village in Lhokseumawe district-Aceh, which then calcinated to be adsorbent. The used material in this research was oyster shell powder with size 100 mesh that had been calcinated at $600^{\circ} \mathrm{C}$ and $800^{\circ} \mathrm{C}$ for 4 hours. Methylene blue (MB) solution as the main solution with $50 \mathrm{mg} / \mathrm{L}(50 \mathrm{ppm})$ concentration was prepared by dissolving distilled water for this research. The MB solution 10 to $40 \mathrm{mg} / \mathrm{L}$ was prepared from $50 \mathrm{mg} / \mathrm{L}$ main solution. The solution of $\mathrm{HCl}$ and $\mathrm{NaOH} 0.5 \mathrm{~N}$ was used to adjust the $\mathrm{pH}$ solution for adsorption process.

\subsection{Methods}

The adsorbate adsorption by adsorbent experiment was conducted to determine the best $\mathrm{pH}$ condition in a $250 \mathrm{~mL}$ Erlenmeyer flask filled with $100 \mathrm{~mL} 50 \mathrm{mg} / \mathrm{L}$ concentration of MB solution; varying $\mathrm{pH}$ from 2 to 11 then 3 grams of adsorbent was poured into conical flask. After that one set of samples filled in $250 \mathrm{~mL}$ was placed in a shaker, shaken with $250 \mathrm{rpm}$ speed at room temperature for 2 hours. After that the samples were filtrated with centrifuge and tested using UV/Vis at $660 \mathrm{~nm}$ wavelength.

For equilibrium adsorption, MB solution was used from 10 to $50 \mathrm{mg} / \mathrm{L}$ with $100 \mathrm{~mL}$ and $\mathrm{pH} 11$. Then 3 grams of adsorbent was poured into conical flask, shaken until equilibrium reached. The MB concentration at the equilibrium, $q_{\mathrm{e}}(\mathrm{mg} / \mathrm{g}) \mathrm{can}$ be calculated with Eqn. (1) [25].

$\mathrm{qe}=\frac{\mathrm{V}\left(\mathrm{C}_{\mathrm{o}}-\mathrm{C}_{\mathrm{e}}\right)}{\mathrm{m}}$ 
$\frac{\mathrm{C}_{\mathrm{e}}}{\mathrm{q}_{\mathrm{e}}}=\frac{1}{\mathrm{q}_{\mathrm{m}} \mathrm{K}}+\frac{\mathrm{C}_{\mathrm{e}}}{\mathrm{q}}$

Where $C_{\mathrm{o}}(\mathrm{mg} / \mathrm{L})$ is initial $\mathrm{MB}$ concentration in liquid phase, $C_{\mathrm{e}}(\mathrm{mg} / \mathrm{L})$ is $\mathrm{MB}$ equilibrium concentration in liquid phase, $V(\mathrm{~mL})$ is total $\mathrm{MB}$ solution volume and $m(\mathrm{~g})$ is mass of adsorbent.

Where $q_{\mathrm{e}}(\mathrm{mg} / \mathrm{g})$ is adsorption density in solute equilibrium concentration. $C_{\mathrm{e}}$ is adsorbate equilibrium concentration in the solution (mg/L). $q_{\mathrm{m}}$ (mg of adsorbed solute per $\mathrm{g}$ adsorbent) is monolayer adsorption maximum capacity. $K$ is Langmuir constant that is related to adsorption energy $(\mathrm{L} / \mathrm{mg})$.

$\ln \mathrm{q}_{\mathrm{e}}=\ln \mathrm{K}_{\mathrm{F}}+\frac{1}{\mathrm{n}} \ln \mathrm{C}_{\mathrm{e}}$

Where $q_{\mathrm{e}}(\mathrm{mg} / \mathrm{g})$ is adsorption density in solute equilibrium concentration. $C_{\mathrm{e}}$ is adsorbate equilibrium concentration in the solution (mg/L). $K_{\mathrm{F}}$ is Freundlich constant related to adsorption capacity, and $n$ is adsorption intensity.

Adsorption kinetics shows the presence of substance adsorption process by adsorbent in time function $(t)$. Adsorption kinetics used solution with initial $\mathrm{MB}$ concentration 10, 20 and $30 \mathrm{mg} / \mathrm{L}$ with volume $250 \mathrm{~mL}$, with adsorbent mass 3 grams, solution pH 11 at room temperature. Then shaken with speed $250 \mathrm{rpm}$ in certain time interval, sample was taken and tested with UV/Vis. Adsorption kinetics testing was evaluated using three kinetic models; pseudo second order model (4), second order model (5) and Ritchie model (6) linearized that as follows.

$$
\begin{gathered}
\frac{\mathrm{t}}{\mathrm{q}_{\mathrm{t}}}=\frac{\mathrm{t}}{\mathrm{q}}+\frac{1}{\mathrm{k}_{1} \mathrm{q}_{\mathrm{e}}^{2}} \mathrm{t} \\
\frac{1}{\mathrm{C}_{\mathrm{e}}}=\mathrm{k}_{2} \mathrm{t}+\frac{1}{\mathrm{C}_{\mathrm{o}}} \\
\frac{\mathrm{q}_{\mathrm{e}}}{\mathrm{q}_{\mathrm{e}}-\mathrm{q}_{\mathrm{t}}}=\beta+\mathrm{k}_{3} \mathrm{t}
\end{gathered}
$$

Where $k_{1}$ is pseudo second order reaction rate constant $\left(\mathrm{g} \mathrm{mg}^{-1} \mathrm{~min}^{-1}\right), k_{2}$ is second order reaction rate constant $\left(\mathrm{L} / \mathrm{mg}\right.$ min), $k_{3}$ is $\mathrm{Ritchie}$ modeled reaction rate constant (min-1), and $\beta$ is Ritchie model constant or in other words can be described as adsorbent concentration when adsorption takes place.

\section{Results and Discussion}

\subsection{Oyster Shell Calcination}

Calcination was conducted in order to eliminate the water content, $\mathrm{CO}_{2}$, other gases including organic compounds bounded with $\mathrm{CaCO}$ in the oyster shell powder. The $\mathrm{CaCO}_{3}$ deformation to be $\mathrm{CaO}$ is shown in equation (7).

$$
\mathrm{CaCO}_{3}(\mathrm{~s}) \rightarrow \mathrm{CaO}(\mathrm{s})+\mathrm{CO}_{2}(\mathrm{~g})
$$

Figure 1 shows color difference from different calcination temperatures. Oyster shell powder produced from $800^{\circ} \mathrm{C}$ calcination process has brighter (slightly white) color compared with calcination process in temperature $800^{\circ} \mathrm{C}$ that has silver color. This was also reported that in egg shell calcination at temperature below $700^{\circ} \mathrm{C}$, the slightly silver color proves that not perfectly CaO was formed[26]. On the other hand,[2] conducted oyster shell calcination too at $900^{\circ} \mathrm{C}$ for 4 hours and it was reported that the formed powder was white, indicating that $\mathrm{CaO}$ was formed perfectly.

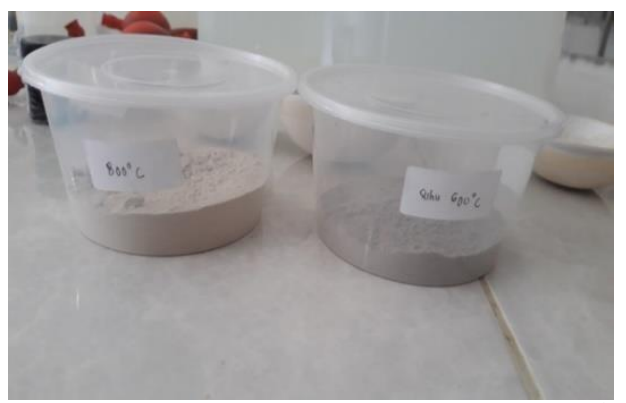

Fig 1. Color difference of oyster shell powder calcinated at $600{ }^{\circ} \mathrm{C}$ and $800{ }^{\circ} \mathrm{C}$

According to the research results, the pre-calcinated mass at $600^{\circ} \mathrm{C}$ and $800^{\circ} \mathrm{C}$ were 84.8006 gr and $101.3494 \mathrm{gr}$ or $15,16 \%$ dan $21,05 \%$ mass reduction percentage. This was due to the high temperature calcination process at $600^{\circ} \mathrm{C}$ and $800 \mathrm{oC}$ for 4 hours was able to decompose $\mathrm{CaCO} 3$ to be calcium oxide $(\mathrm{CaO})$ and carbon dioxide gas $(\mathrm{CO} 2)$.

The oyster shell powder that was calcinated at $600^{\circ} \mathrm{C}$ and $800^{\circ} \mathrm{C}$ with values of $84.8006 \mathrm{~g}$ and $101.3494 \mathrm{~g}$ produced $71.9400 \mathrm{~g}$ and 80.0122 $\mathrm{g} \mathrm{CaO}$ respectively. Therefore, $13.4512 \mathrm{~g}$ and $21.3372 \mathrm{~g}$ oyster shell powder decomposed into $\mathrm{CO}_{2}$ gas.

\section{2. pH Effect}

Before adsorption research was conducted, the adsorption capacity testing by $\mathrm{pH}$ effect was needed to be done. The optimum $\mathrm{pH}$ variation was set to comprehend oyster shell adsorbent's adsorption capability of methylene blue dying material; thus, the adsorbent's function could be utilized optimally. As it is shown in Figure 2, the adsorption was not significant in the range of $\mathrm{pH} 2$ to 10 , which was (1.2 mg/g). The maximum adsorption is clearly shown at the condition $\mathrm{pH} 11$, which was $1.5 \mathrm{mg} / \mathrm{g}$. 


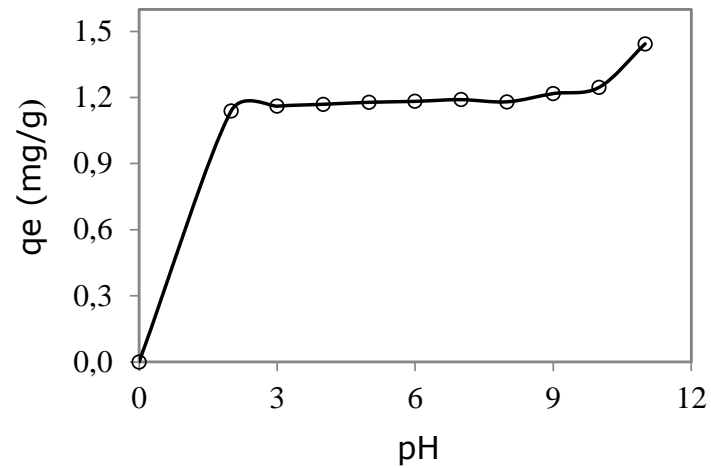

Fig 2. $\mathrm{pH}$ and adsorption capacity (qe) correlation curve with initial $\mathrm{MB}$ concentration $50 \mathrm{mg} / \mathrm{L}$ and adsorbent mass $3 \mathrm{gr}$

Figure 2 shows that the more acidic the solution was, the less adsorption value (qe), meanwhile the adsorption value was higher in more basic solution; this implies that the maximum adsorption took place in basic condition. Hence, oyster shell powder adsorbed MB optimally at $\mathrm{pH} 11$. Examining the adsorption percentage, it is clear that the adsorption percentage at $\mathrm{pH} 11$ was $86.59 \%$. The same phenomenon was reported by [27] that the MB adsorption was at the highest percentage at $\mathrm{pH} 12$ with value $98.97 \%$.

\subsection{Adsorption Equilibrium}

Adsorption rate testing was conducted to determine the duration for equilibrium to take place by the utilized adsorbent. The equilibrium has been utilized based on Langmuir for adsorption of dye material in wastewater [28]. The adsorption isotherm according to Langmuir equation based on MB adsorbate with different initial concentrations and varying calcinated adsorbent is shown in Figures 3 and 4 . Figures 3 and 4 were based on equation (2). In Langmuir equation if $0<\mathrm{RL}<1$ then the adsorption is said to be favorable, RL > 1 expresses unfavorable, $\mathrm{RL}=1$ is linear adsorption and $\mathrm{RL}=0$ implies irreversible process.

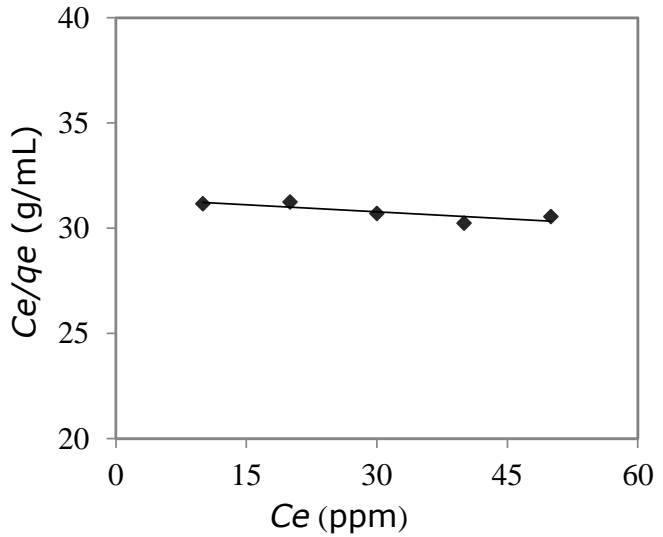

Fig 3. Adsorbent Langmuir equation at calcination temperature $600^{\circ} \mathrm{C}$

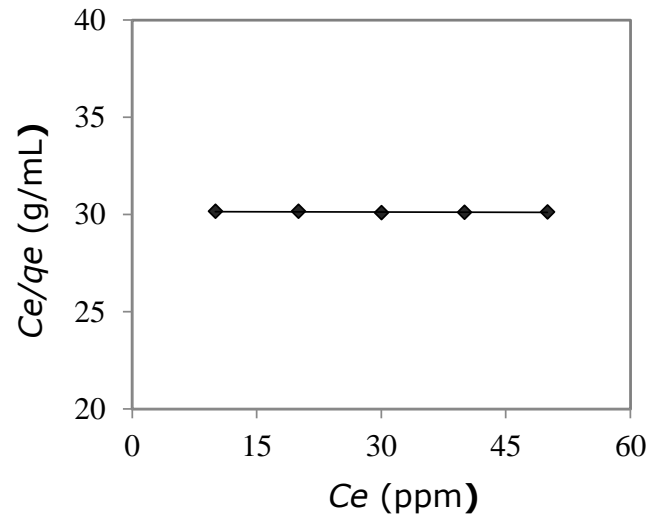

Fig 4. Adsorbent Langmuir equation at calcination temperature $800^{\circ} \mathrm{C}$

For Freundlich equation in Figures 5 and 6; when $0<\mathrm{n}<1$ then the adsorption is favorable and shows cooperative adsorption. The $\mathrm{n}$ values are in the range of 1-10[29].

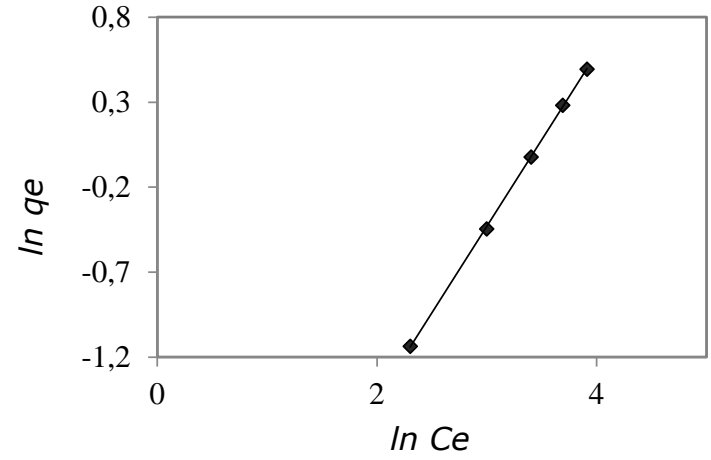

Fig 5. Adsorbent Freundlich equation at calcination temperature $600^{\circ} \mathrm{C}$

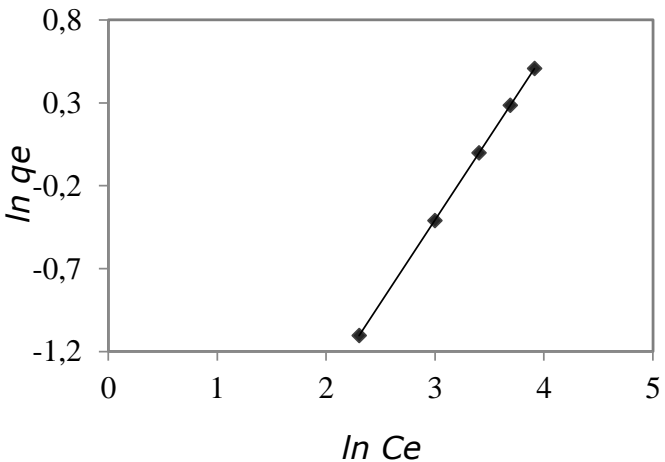

Fig 6. Adsorbent Freundlich equation at calcination temperature $800^{\circ} \mathrm{C}$

Table 1 tabulates model parameters that were used in adsorption process using calcinated adsorbent at different temperatures. The adsorption process is well described by linear equation of Freundlich isotherm with correlation coefficient R $2=0.9999$ and adsorption intensity $\mathrm{n}$ close to one; this shows that the adsorption was multilayer or in other heterogeneous adsorption energy. 
According to Langmuir equation that shows that the adsorption process by oyster shell was higher at $800^{\circ} \mathrm{C}$ compared to $600^{\circ} \mathrm{C}$ for the calcination temperatures. This shows the rise in activation temperature raises the surface area of adsorbent pores, hence increases the maximum adsorption capacity.

\subsection{Adsorption Kinetics Study}

A well-known adsorption kinetics mechanism undergoes through three consecutive steps[29].

1. Adsorbate transfer from bulk to film around the adsorbent

2. Adsorbate transfer film the adsorbent surface with the direction to adsorption surface.

3. Adsorbate diffusion form surface to internal site followed with adsorbates binding with active sites.

Table 1. The Langmuir and Freundlich equations parameters using adsorbent at different calcination temperatures

\begin{tabular}{cccccccc}
\hline & \multicolumn{3}{c}{ Isoterm Langmuir } & \multicolumn{3}{c}{ Isoterm Freundlich } \\
\cline { 2 - 7 } Adsorbent & $q_{\max }(\mathrm{mg} / \mathrm{g})$ & $K_{\mathrm{L}}(\mathrm{L} / \mathrm{mg})$ & $R_{\mathrm{L}}(\mathrm{L} / \mathrm{g})$ & $R^{2}$ & $K_{\mathrm{F}}(\mathrm{L} / \mathrm{g})$ & $n$ & $R^{2}$ \\
\hline $\mathrm{T}=600^{\circ} \mathrm{C}$ & 0.0318 & $-7.1 \times 10-4$ & 1.0365 & 0.6978 & 0.0307 & 0.9826 & 0.9999 \\
\hline $\mathrm{T}=800^{\circ} \mathrm{C}$ & 0.0331 & $-3.97 \times 10-5$ & 1.0019 & 0.3511 & 0.0331 & 0.9989 & 0.9999 \\
\hline
\end{tabular}

\subsubsection{Pseudo Second Order Model}

Pseudo second order equation was analyzed in order to assume that adsorption value was proportional to number of adsorbents active sites (shown in figures 7 and 8). Pseudo second order was evaluated according to adsorption values at different solution concentration. MB

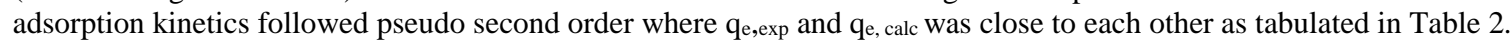

The data in Table 2 also explains that the overall adsorbent calcination correlation coefficient experimental results (R2) at $800^{\circ} \mathrm{C}$ is higher compared with $600^{\circ} \mathrm{C}$ calcination process, in the range of $0.9984-0.999$. The pseudo second order could also explain the adsorption rate was controlled by chemisorption in the MB adsorption to oyster shell adsorbent affected by valence force through electron transfers between MB and oyster shell adsorbent.

Table 2. Pseudo Second Order Parameters using Calcinated Adsorbent at Different Temperatures

\begin{tabular}{|c|c|c|c|c|c|c|c|c|}
\hline \multirow{2}{*}{$\begin{array}{c}\text { Conc } \\
(\mathrm{mg} / \mathrm{L})\end{array}$} & \multicolumn{4}{|c|}{$600^{\circ} \mathrm{C}$ Adsorbent Parameters } & \multicolumn{4}{|c|}{$800^{\circ} \mathrm{C}$ Adsorbent Parameters } \\
\hline & $q_{e, \exp }(\mathrm{mg} / \mathrm{g})$ & $q_{e, \text { calc }}(\mathrm{mg} / \mathrm{g})$ & $\begin{array}{c}k \\
(\mathrm{~g} / \mathrm{mg} \min )\end{array}$ & $R^{2}$ & $q_{e, \exp }(\mathrm{mg} / \mathrm{g})$ & $q_{e, \text { calc }}(\mathrm{mg} / \mathrm{g})$ & $\begin{array}{c}k \\
(\mathrm{~g} / \mathrm{mg} \min )\end{array}$ & $R^{2}$ \\
\hline 10 & 0,7530 & 0,2172 & 0,0628 & 0,9534 & 0,7754 & 0,8575 & 0,9456 & 0,9991 \\
\hline 20 & 1,6043 & 1,6469 & 1,8216 & 0,9782 & 1,5190 & $-2,6247$ & $-4,4566$ & 0,9984 \\
\hline 30 & 2,3658 & 2,212 & 2,0761 & 0,9991 & 2,4017 & 13,072 & 71,169 & 0,9999 \\
\hline
\end{tabular}

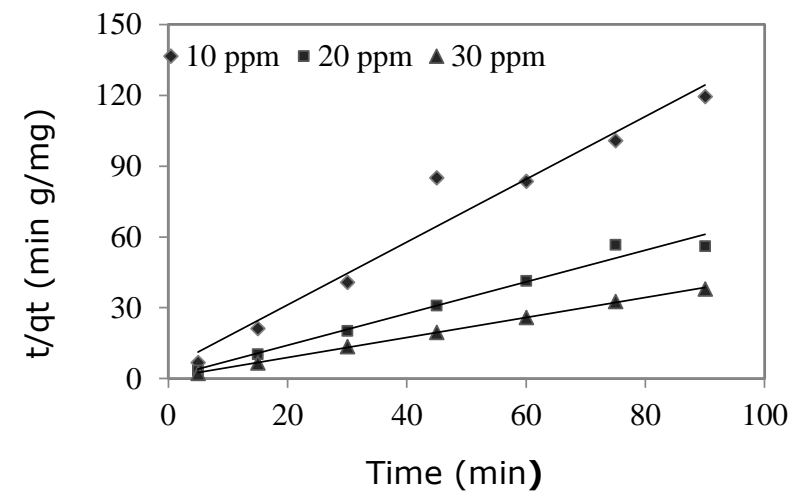

Fig 7. Pseudo Second Order Curve at $600^{\circ} \mathrm{C}$ Calcination

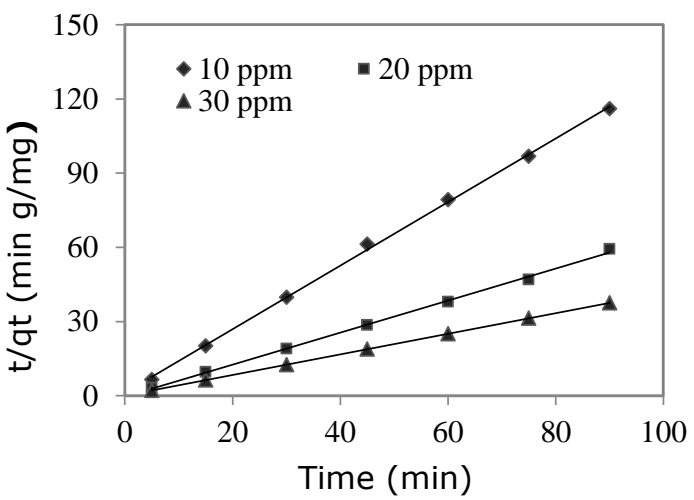

Fig 8. Pseudo Second Order Curve at $800^{\circ} \mathrm{C}$ Calcination

\subsubsection{Second Order Model}

Second order model is affected by the two reacting reagents' concentrations. The applied second order equation on solid-liquid system describing oyster shell adsorbent and methylene blue are shown in Figures 9 and 10. The parameters from order equation are tabulated in 
Table 3. From Table 3, it can be understood that second order equation could not explain the adsorption process and description of the entire contact time, especially the adsorbate at low concentrations.

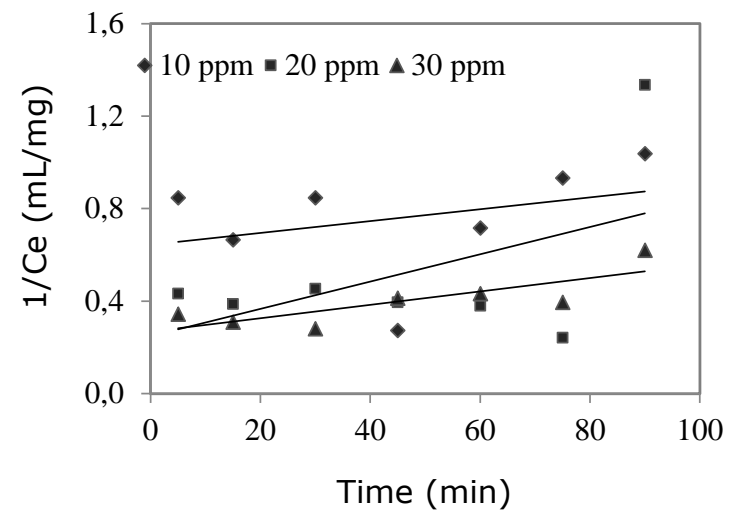

Fig 9. second Order Curve at $600^{\circ} \mathrm{C}$ Calcination

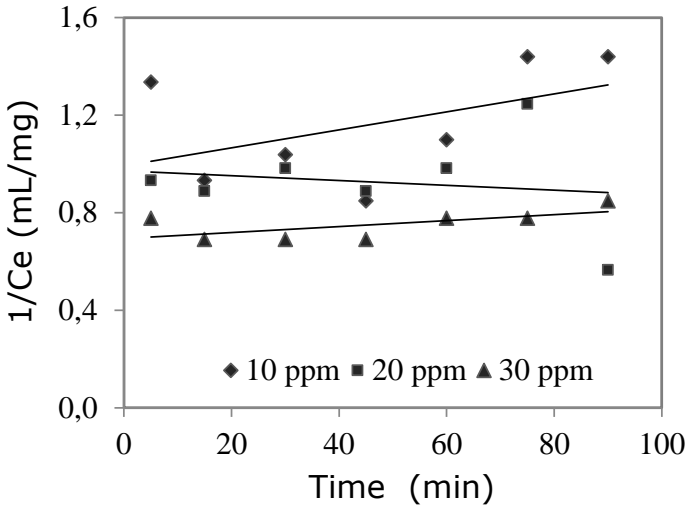

Fig 10. Second Order Curve at $800^{\circ} \mathrm{C}$ Calcination

Table 3. Second order parameters using calcinated adsorbent at different temperatures

\begin{tabular}{ccccccccc}
\hline \multirow{2}{*}{$\begin{array}{c}\text { Conc } \\
(\mathrm{mg} / \mathrm{L})\end{array}$} & $\begin{array}{c}C_{0, \exp } \\
(\mathrm{mg} / \mathrm{L})\end{array}$ & $\begin{array}{c}C_{0, \text { calc }} \\
(\mathrm{mg} / \mathrm{L})\end{array}$ & $\begin{array}{c}k(\mathrm{~L} / \mathrm{mg} \\
\mathrm{min})\end{array}$ & $R^{2}$ & $\begin{array}{c}C_{0, \exp } \\
(\mathrm{mg} / \mathrm{L})\end{array}$ & $\begin{array}{c}C_{0, \text { calc }} \\
(\mathrm{mg} / \mathrm{L})\end{array}$ & $\begin{array}{c}k \\
(\mathrm{~L} / \mathrm{mg} \\
\mathrm{min})\end{array}$ & $R^{2}$ \\
\hline 10 & 0.964 & 1.5542 & 0.0026 & 0.104 & 0.695 & 1.0067 & 0.0037 & 0.2248 \\
\hline 20 & 0.749 & 4.0323 & 0.0059 & 0.254 & 1.772 & 1.0289 & -0.001 & 0.0238 \\
\hline 30 & 1.610 & 3.7383 & 0.0029 & 0.654 & 1.179 & 1.4415 & 0.0012 & 0.3961 \\
\hline
\end{tabular}

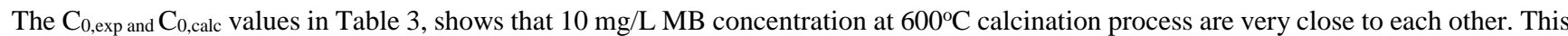
shows that at high concentration the adsorbate was not well adsorbed by whole area of adsorbent causing adsorption equilibrium is not in linear part. However, adsorbent at $800^{\circ} \mathrm{C}$ calcination process with $\mathrm{MB}$ adsorbate concentrations from 10 to $30 \mathrm{mg} / \mathrm{L}$ had $\mathrm{C} 0$,exp and $\mathrm{C} 0$, calc values not very from each other. This is due to the OS adsorbent was effective enough to adsorb MB in the solution.

\subsubsection{Ritchie Model}

Ritchie model was first used to describe kinetic adsorption in gas-solid phase; despite its broad application to liquid-solid adsorption. This model was proposed by Ritchie as alternative to Elovich model. The essential assumption from Ritchie model is one adsorbate is adsorbed by both two sites surface[30]. In other words, Ritchie equation assumes every adsorbent surface has $\mathrm{n}$ surface site that depends one adsorbate molecule (ion). Through Ritchie equation as shown in Figures 11 and 12, OS adsorbent was able to describe MB adsorption at low concentration.

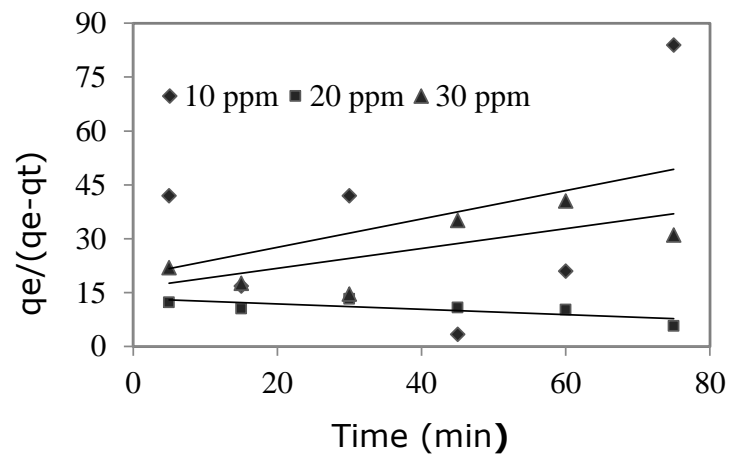

Fig 11. Ritchei Model Curve at $600^{\circ} \mathrm{C}$ Calcination

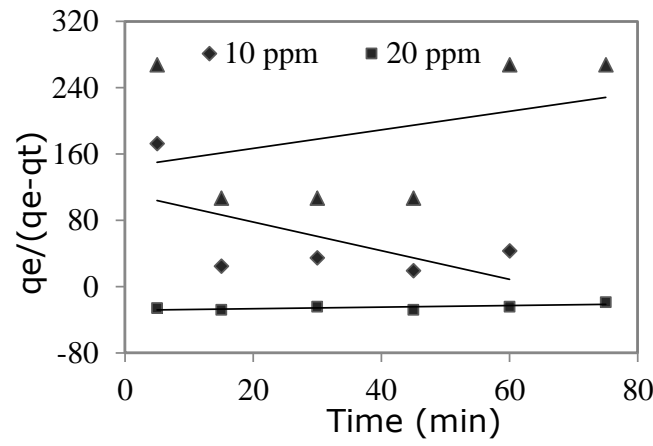

Fig 12. Ritchie Model Curve at $800^{\circ} \mathrm{C}$ Calcination

Table 4 presents the Ritchie equation parameters. The broad adsorbent surface made OS adsorbent took place in heterogeneous condition. As it can be seen, Ritchie explains adsorption mechanism as physical adsorption.

Tabel 4. Ritchie equation parameters using calcinated adsorbent at different temperatures

\begin{tabular}{|c|c|c|}
\hline Conc $(\mathrm{mg} / \mathrm{L})$ & $600^{\circ} \mathrm{C}$ Adsorbent Parameters & $800^{\circ} \mathrm{C}$ Adsorbent Parameters \\
\hline
\end{tabular}




\begin{tabular}{|c|c|c|c|c|c|c|}
\hline & $k\left(\min ^{-1}\right)$ & $\beta$ & $R^{2}$ & $k\left(\min ^{-1}\right)$ & $\beta$ & $R^{2}$ \\
\hline 10 & 0,3945 & 19,695 & 0,1388 & $-1,17263$ & 112,4 & 0,3545 \\
\hline 20 & $-0,074$ & 13,303 & 0,571 & 0,091 & 28,426 & 0,4838 \\
\hline 30 & 0,2751 & 16,271 & 0,509 & 1,1202 & 144,38 & 0,1163 \\
\hline
\end{tabular}

\section{Conclusion}

Oyster shell (OS) powder calcination as adsorbent was conducted convert $\mathrm{CaCo} 3$ into $\mathrm{CaO}$. Oyster shell powder that was calcinated at $800 \mathrm{oC}$ had brighter (slightly white) color due formation of calcium oxide more perfectly compared to calcination process at $600 \mathrm{oC}$ with silver color. Adsorption process at the equilibrium follows Freundlich isotherm model with constant (KF) value $0.0300 \mathrm{~L} / \mathrm{g}$ using $600 \mathrm{oC}$ calcinated adsorbent and $0.0031 \mathrm{~L} / \mathrm{g}$ using $800 \mathrm{oC}$ calcinated adsorbent with correlation coefficient value R2=0,9999.

Oyster shell adsorption kinetics calcination at $600 \mathrm{oC}$ and $800 \mathrm{oC}$ to adsorb methylene blue (MB) tended to fit on pseudo second order equation with correlation coefficient (R2) ranges from 0.9534-0.9999. The reaction rate for this model was determined to be between $4,4566-71,169 \mathrm{~g} / \mathrm{mg} \mathrm{min}$.

\section{References}

[1] H. Yanti, M. Muliani, and M. Khalil, "Pengaruh salinitas yang berbeda terhadap tingkat pertumbuhan dan kelangsungan hidup tiram (Crassostrea sp)," Acta Aquat. Aquat. Sci. J., vol. 4, no. 2, pp. 53-58, 2017.

[2] L. Handayani and F. Syahputra, "Isolasi dan karakterisasi nanokalsium dari cangkang tiram (Crassostrea gigas)," JPHPI, vol. 20, no. 3 , pp. 515-523, 2017.

[3] E. C. Siregar, S. Suryati, and L. Hakim, "Pengaruh suhu dan waktu reaksi pada pembuatan kitosan dari tulang sotong (Sepia officinalis)," J. Teknol. Kim. Unimal, vol. 5, no. 2, pp. 37-44, 2017.

[4] A. Aji and M. Meriatna, "Pembuatan Kitosan Dari Limbah Cangkang Kepiting," J. Teknol. Kim. Unimal, vol. 1, no. 1, pp. 79-90, 2017.

[5] K. Navi and E. Navi, "Nonlinear effect of changing the temperature to overcome Covid-19," International Journal of Nonlinear Analysis and Applications, vol. 11, no. 1. 2020, doi: 10.22075/IJNAA.2020.4355.

[6] Y. H. Zhang, Y. S. Szeto, S. J. Ke, W. Tan, and L. B. Liao, "Dyeing and finishing effluent treatment with chitosan/inorganic composites," in Key Engineering Materials, 2007, vol. 334, pp. 1069-1072.

[7] G. Z. Kyzas, M. Kostoglou, A. A. Vassiliou, and N. K. Lazaridis, "Treatment of real effluents from dyeing reactor: Experimental and modeling approach by adsorption onto chitosan," Chem. Eng. J., vol. 168, no. 2, pp. 577-585, 2011.

[8] B. Guan, W. Ni, Z. Wu, and Y. Lai, "Removal of Mn (II) and Zn (II) ions from flue gas desulfurization wastewater with watersoluble chitosan," Sep. Purif. Technol., vol. 65, no. 3, pp. 269-274, 2009.

[9] T. Y. Liu, L. Zhao, and Z. L. Wang, "Removal of hexavalent chromium from wastewater by Fe0-nanoparticles-chitosan composite beads: characterization, kinetics and thermodynamics," Water Sci. Technol., vol. 66, no. 5, pp. 1044-1051, 2012.

[10] N. A. Oladoja, C. M. A. Ademoroti, and I. O. Asia, "Treatment of industrial effluents using fortified soil-clay," Desalination, vol. 197, no. 1-3, pp. 247-261, 2006.

[11] N. Kadkhoda, H. Jafari, and R. M. Ganji, “A numerical solution of variable order diffusion and wave equations,” Int. J. Nonlinear Anal. Appl., vol. 12, no. 1, 2020, doi: 10.22075/ijnaa.2021.4652.

[12] W. S. \& K. Wong et al., “No 主観的健康感を中心とした在宅高齢者における 健康関連指標に関する共分散構造分析Title,” J. Pendidik. Malaysia, 2018.

[13] R. Rinaldy and M. Ikhsan, "Determinant Analysis Of Conflict On Project Results In Aceh Province," Int. J. Eng. Sci. Inf. Technol., vol. 1, no. 1, 2021, doi: 10.52088/ijesty.v1i1.37.

[14] Z. Azmi, "Artificial Neural Network Model For Wind Mill," Int. J. Eng. Sci. Inf. Technol., vol. 1, no. 3, 2021, doi: 10.52088/ijesty.v1i3.84.

[15] Z. Soares Lopes, F. Kurniawan, and J. Tistogondo, "Case Study of Public-Private Partnership on Infrastruc-ture Projects of Tibar Bay Port in Timor-Leste,” Int. J. Eng. Sci. Inf. Technol., vol. 1, no. 3, 2021, doi: 10.52088/ijesty.v1i3.79.

[16] F.-C. Tsai et al., "Adsorptive removal of methyl orange from aqueous solution with crosslinking chitosan microspheres," J. Water Process Eng., vol. 1, pp. 2-7, 2014.

[17] R. H. Buti and A. K. Sachit, "On subclass of analytic univalent functions defined by fractional differ-integral operator i," Int. J. Nonlinear Anal. Appl., vol. 12, no. Special Issue, 2021, doi: 10.22075/IJNAA.2021.4844.

[18] R. R. Siregar, "STRUKTUR POPULASI TIRAM PASIFIK ( Crassostrea gigas, Thunberg 1793 ) DI PABEAN ILIR, INDRAMAYU," 2017.

[19] L. Handayani and F. Syahputra, "Isolasi dan Karakteristik Nanokalsium dari Cangkang Tiram (Crassostrea gigas)," J. Pengolah. Has. Perikan. Indones., vol. 20, pp. 515-523, 2017.

[20] L. Maghfiroh, "Adsorpsi zat warna tekstil remazol brilliant blue menggunakan zeolit yang disintesis dari abu layang batubara," 2016.

[21] A. Tahad and A. S. Sanjaya, "Isoterm Freundlich, Model Kinetika, dan Penentuan Laju Reaksi Adsorpsi Besi dengan Arang Aktif dari Ampas Kopi,” J. Chemurg., vol. 1, no. 2, pp. 13-21, 2018.

[22] A. S. Sanjaya and R. P. Agustine, "Studi Kinetika Adsorpsi Pb Menggunakan Arang Aktif dari Kulit Pisang," Konversi, vol. 4, no. 1, pp. 17-24, 2015.

[23] P. Kurniawatia, B. Wiyantokoa, A. Kurniawanb, and Tri Esti Purbaningtias, "Kinetic study of Cr(VI) Adsorption on Hydrotalcite Mg/Al with Molar Ratio 2:1,” EKSAKTA, vol. 13, no. 1-2, pp. 11-21, 2013. 
[24] M. F. J. D. P. Tanasale, A. Killay, and M. S. Laratmase, "Kitosan dari Limbah Kulit Kepiting Rajungan ( Portunus sanginolentus L .) sebagai Adsorben Zat Warna Biru Metilena," J. Natur Indones., vol. 14, no. 2, pp. 165-171, 2014.

[25] Muhammad, T. G. Chuah, Y. Robiah, A. R. Suraya, and T. S. Y. Choong, "Single and binary adsorptions isotherms of Cd (II) and Zn (II) on palm kernel shell based activated carbon," Desalin. Water Treat., vol. 29, no. 1-3, pp. 140-148, 2011.

[26] C. L. K. Nazar, Muhammad,. Syahrial,. \& Sari, "Pembuatan CaO dari Cangkang Telur sebagai Katalis Untuk Konversi Minyak Kelapa menjadi Biodiesel,” Sains Sci. Educ. Proceeding Natl. Semin., vol. 22, 2013.

[27] D. Anggraini, "PENGARUH SUHU AKTIVASI CANGKANG TELUR TERHADAP DAYA SERAP METILEN BIRU," ETD Unsyiah, 2016.

[28] T. Kou, Y. Wang, C. Zhang, J. Sun, and Z. Zhang, "Adsorption behavior of methyl orange onto nanoporous core-shell Cu@ Cu2O nanocomposite,” Chem. Eng. J., vol. 223, pp. 76-83, 2013.

[29] V. Vadivelan and K. V. Kumar, "Equilibrium, kinetics, mechanism, and process design for the sorption of methylene blue onto rice husk," J. Colloid Interface Sci., vol. 286, no. 1, pp. 90-100, 2005.

[30] C. W. Cheung, J. F. Porter, and G. McKay, "Sorption kinetic analysis for the removal of cadmium ions from effluents using bone char," Water Res., vol. 35, no. 3, pp. 605-612, 2001. 